\title{
New era in cancer immunotherapy: Twenty years to the discovery of monoclonal antibodies harnessing the immune system to eradicate tumors
}

\author{
Britta Hardy, Annat Raiter \\ Felsenstein Medical Research Center, Tel-Aviv University School of Medicine, Rabin Medical Center, Petach-Tikva, Israel \\ Email: bhardy@post.tau.ac.il
}

Received January $15^{\text {th }}$, 2013; revised March $13^{\text {th }}, 2013$; accepted April 17 ${ }^{\text {th }}, 2013$

Copyright (C) 2013 Britta Hardy, Annat Raiter. This is an open access article distributed under the Creative Commons Attribution License, which permits unrestricted use, distribution, and reproduction in any medium, provided the original work is properly cited.

\begin{abstract}
The better understanding of the mechanism in which the immune system responds to the developing cancer provided the outcome in a new era in cancer immunotherapy. The tumor suppressive effect on the immune system is caused by negative $T$ cell receptor signaling that abrogate immunity against the cancer cells. Novel monoclonal antibodies that target co-inhibitory receptors on $T$ cells block the tumor induced inhibition of the immune system and enable the immune system to eradicate the tumors. The development of such antibodies started twenty years ago by the preparation of a monoclonal antibody termed BAT. A single administration of the antibody to tumor bearing mice resulted in striking anti tumor activity that was mediated by the lymphocytes. These studies provided a basis for the new era of cancer immunotherapy. The present review summarizes twenty years to the discovery of monoclonal antibodies harnessing the immune system to eradicate tumors.
\end{abstract}

Keywords: Cancer Immunotherapy; Monoclonal Antibodies; Anergy; T Cell Receptors

\section{INTRODUCTION}

The interaction between cancer cells and the host immune system exhibits an intriguing and dynamic clash for life. Tumor progression under immune pressure includes three major motions: elimination, equilibrium and escape [1,2]. In the first phase, the innate and adaptive immune system abolishes nascent tumor cells (immune surveillance) [3]. If not all cancer cells are eliminated, the second phase is the equilibrium between cancer and the immune system, in which the tumor remains dormant temporarily. The interaction between cancer cells and the host immune system induces inhibitory immune reac- tions that result in tumor escape and the development of clinically evident disease [1,4-7].

In the past, several approaches have been used to harness and stimulate the immune system to fight cancer such as vaccination of cancer patients with vaccine against tuberculosis BCG [8-10] that induced cellular immune responses. Stimulation of cellular immunity was also experimented by the administration of large numbers of $T$ cells from tumor-infiltrating lymphocytes or engineered $\mathrm{T}$ cells to express receptors for specific tumor-associated antigens (TAA) [11,12]. Immunization was further studied with peptide-pulsed or tumor lysate-pulsed dendritic cells $[13,14]$ and cytokine-mediated immune therapy $[7$, 15].

However, the success of such activation of the immune system to fight cancer remained poor and was unsatisfactory for clinical immunotherapy $[16,17]$.

In the last 20 years immunotherapy has been undergoing an exclusive progress resulting from new understanding of the mechanism in which the immune system responds to the developing cancer $[18,19]$. The developing cancer induces a state of "anergy" in which the immune system is not activated to fight the tumor. The new cancer immunotherapy, different from the previous approach, is to activate the immune system by releasing it from the suppressive effect of the developing cancer [20-22].

In order to achieve clinical proof of this concept, this approach included the development of novel monoclonal antibodies that block the tumor-induced inhibition of the immune system thus enabling the immune system to eradicate tumors.

\section{NEGATIVE T CELL RECEPTOR SIGNALING THAT ABROGATE IMMUNITY AGAINST CANCER CELLS}

Several activation signals are required to induce the 
cellular immunity. The first signal for $\mathrm{T}$ cell activation requires the major histocompatibility complex (MHC) recognition on the tumor cell by the T cell CD3 receptor [23]. However MHC binding by itself is insufficient for producing a $\mathrm{T}$ cell response. Lack of further stimulatory signals will send the immune response into "anergy" [22, 24].

A second signal is necessary in order to continue the immune response. This signal can come from co-stimulatory molecules. One such source of a second signals is the $\mathrm{T}$ cell binding receptors peripheral membrane proteins of the B7 family $[22,25,26]$. The B7 family of cosignaling molecules is expressed on the surface of antigen presenting cells (APC) and also on T lymphocytes. These co-signaling molecules provide significant positive signals that stimulate T-cell growth, up-regulate cytokine production and promote T-cell differentiation. In parallel, they also provide negative co-signaling molecules that contribute for the impediment of immunologic tolerance or attenuate T-cell responses [22-28].

A primary co-stimulatory signal is delivered through the binding of the $\mathrm{T}$ cell receptor CD28 to its ligands B7-1 (CD80) or B7-2 (CD86).

An inhibitory T cell receptor CTLA-4 (CD152) binds the same B7-1 or B7-2 ligands with twenty-times greater affinity. As a result, the $\mathrm{T}$ cell is blocked from receiving the $\mathrm{B} 7$ protein signal by CD28 co-stimulatory molecule and is therefore not activated. Binding of the B7 to CTLA-4 causes inhibition (or "anergy") of the T-cell activity $[22,29,30]$.

A second recently defined inhibitory receptor, whose expression can be induced primarily on the cell surface of activated $\mathrm{T}$ cells is the programmed death- 1 receptor (PD-1) [31]. PD1 is a 50 - $55 \mathrm{kDa}$ trans-membrane receptor that was identified in a $\mathrm{T}$ cell line undergoing activation induced cell death [31]. PD-1 was also found to be highly expressed on induced regulatory T cells (iTregs) suggesting an additional mechanism for immunosuppression in a tumor microenvironment [32].

Monoclonal antibodies directed against such tumor immune negative co-stimulatory receptors, suggested a promising novel approach for anticancer immunotherapy based on promoting immune responses against cancer as well as breaking up tumor resistance and dormancy.

\section{THE USE OF ANTIBODIES IN CANCER THERAPY}

The use of monoclonal antibodies in cancer therapy was based for many years on antibodies that target determinants on the cancer cell itself. Since determinants on cancer cells were not steady due to tumor alterations, that approach was found to be insufficient in cancer therapy [33].
The new immunotherapy uses antibodies targeting co-inhibitory receptors on $\mathrm{T}$ cells that block the tumorinduced inhibition of the immune system. This enhances the immune function against the tumor, leading to successful clinical trials currently determining eradication of tumors.

The development of such monoclonal antibodies started twenty years ago. A monoclonal antibody prepared against cell membranes of Daudi cells was investigated. This antibody, termed BAT, was found to induce T cell proliferation and increase cytotolytic activity in human peripheral blood cells [34]. Administration of BAT monoclonal antibody to experimental tumor bearing mice demonstrated striking anti tumor activities in a wide range of both murine and human tumors [35-39].

It was for the first time that antitumor activity was achieved by adoptive transfer of lymphocytes from BAT treated mice to tumor bearing recipients. The transfer of lymphocytes that induced tumor regression demonstrated that the lymphocytes alone mediated the anti-tumor activity. Mice that were cured of tumor were also partially resistant to further challenge with the tumor [35]. The anti tumor activity mediated by lymphocytes was also demonstrated in SCID mice that were engrafted with human lymphocytes against human melanoma [36].

The mechanism of action of BAT determined that NK or T cells mediated the antitumor effect of BAT [35] and the primary cellular target for BAT in human peripheral blood cells were $\mathrm{CD}^{+} \mathrm{T}$ cells that stimulated the secretion of IFN- $\gamma$ [40]. The local secretion of IFN- $\gamma$ induces an anti-tumor response by recruitment of host immune cells to the tumor resulting in a successful host anti-tumor immune response. Stimulation of $\mathrm{CD}^{+} \mathrm{T}$ cells in association with NK cells produces a cascade of events leading to the development of a $T_{h} 0$ or $T_{h} 1$ response or to a shift of a $T_{h} 2$ response towards a $T_{h} 1$ or $\mathrm{T}_{\mathrm{h}} 0$ profile. Assuming that NK cells can influence $\mathrm{CD} 4^{+}$ and that $\mathrm{CD} 4^{+} \mathrm{T}$ cells are able to facilitate the generation of $\mathrm{CD}^{+}$cytotoxic $\mathrm{T}$ lymphocytes (CTL) through their elaboration of cytokines, the interaction between NK cells, activated $\mathrm{CD}^{+} \mathrm{T}$ cells and $\mathrm{CD} 8^{+} \mathrm{CTL}$ precursors contributes to the induction of effector CTL [40].

The potential clinical use of BAT monoclonal antibody was demonstrated against a wide range of tumors, confirming the inhibition of the "anergy" induced by the tumor on the immune system.

A single injection of BAT resulted in the reduction of leukemia/lymphoma cells. Anti-tumor effect was also obtained when animals were injected with splenocytes from BAT-treated donor mice [37]. Anti tumor effect of the humanized form of BAT, termed CT011, was demonstrated against human colorectal carcinoma (CRC) in nude mice with liver metastases that were replaced by lymphocytes [38]. 
The anti-tumor activity of BAT provided the basis for its potential use in human immunotherapy. It was demonstrated that a single administration of 0.2 to $6.0 \mathrm{mg} / \mathrm{kg}$ of CT-011 is safe and well tolerated in patients with advanced hematologic malignancies. The observed clinical benefits may be related to durable tumor-specific immune response that is induced by CT-011 [41]. A phase II clinical study evaluated the safety and efficacy of CT-011 administered at the dose level of $1.5 \mathrm{mg} / \mathrm{kg}$ in diffuse large B-cell lymphoma following autologous bone marrow transplantation. CT-011 dose was chosen based on the pharmacokinetic analysis done in this phase I study as well as on comparability to efficacy and pharmacokinetic parameters obtained in studies conducted in animal models.

\section{CONCLUSION}

These studies provided the basis for the new era of cancer immunotherapy that uses monoclonal antibodies that target CTLA4 and PD-1 thus enable the immune system to eradicate the tumor [42]. Nevertheless it seems that other receptors with similar properties are expressed by $\mathrm{T}$ cells and may be also recruited to immunotherapy to improve cancer treatment in the future.

\section{ACKNOWLEDGEMENTS}

The authors wish to express their profound gratitude and appreciation to the late Professor David Givol of the Weizmann Institute of Science (who deceased while writing this review), for his encouragement and continuous interest in our contribution to cancer immunotherapy.

\section{REFERENCES}

[1] Chow, M.T., Moller, A. and Smyth, M.J. (2012) Inflammation and immune surveillance in cancer. Seminars in Cancer Biology, 22, 23-32. doi:10.1016/j.semcancer.2011.12.004

[2] Villalba, M., Rathore, M.G., Lopez-Royuela, N., Krzywinska, E., Garaude, J. and Allende-Vega N. (2013) From tumor cell metabolism to tumor immune escape. The International Journal of Biochemistry \& Cell Biology, 45, 106-113. doi:10.1016/j.biocel.2012.04.024

[3] Dunn, G.P., Bruce, A.T., Ikeda, H., Old, L.J. and Schreiber, D. (2002) Cancer immunoediting: From immunosurveillance to tumor escape. Nature Immunology, 3, 991998. doi:10.1038/ni1102-991

[4] Shankaran, V., Ikeda, H., Bruce, A.T., White, J.M., Swanson, P.E., Old, L.J. and Schreiber, R.D. (2001) IFNg and lymphocytes prevent primary tumour development and shape tumour immunogenicity. Nature, 410, 1107-1111. doi:10.1038/35074122

[5] Browning, M.J. and Bodmer, W.F. (1992) MHC antigens and cancer: Implications for T-cell surveillance. Current Opinion in Immunology, 4, 613-618. doi:10.1016/0952-7915(92)90036-E
[6] Reed, J.C. (1999) Mechanisms of apoptosis avoidance in cancer. Current Opinion in Oncology, 11, 68-72. doi:10.1097/00001622-199901000-00014

[7] Ben-Baruch, A. (2006) Inflammation-associated immune suppression in cancer: The roles played by cytokines, chemokines and additional mediators. Seminars in Cancer Biology, 16, 38-52. doi:10.1016/j.semcancer.2005.07.006

[8] Kresowik, T.P. and Griffith, T.S. (2009) Bacillus calmetteGuerin immunotherapy for urothelial carcinoma of the bladder. Immunotherapy, 1, 281-288. doi:10.2217/1750743X.1.2.281

[9] Raez, L.E., Fein, S. and Podack, E.R. (2005) Lung cancer immunotherapy. Clinical Medicine \& Research, 3, 221228. doi:10.3121/cmr.3.4.221

[10] Dalgleish, A.G. (2000) Cancer vaccines. British Journal of Cancer, 82, 1619-1624.

[11] Urbanska, K., Lanitis, E., Poussin, M., Lynn, R.C., Gavin, B.P., Kelderman, S., Yu, J., Scholler, N. and Powell Jr., D.J. (2012) A universal strategy for adoptive immunotherapy of cancer through use of a novel t-cell antigen receptor. Cancer Research, 72, 1844-1852. doi:10.1158/0008-5472.CAN-11-3890

[12] Bear, A.S. Cruz, C.R. and Foster, A.E. (2011) T cells as vehicles for cancer vaccination. Journal of Biomedicine and Biotechnology, 2011, Article ID: 417403.

[13] Teitz-Tennenbaum, S., Wicha, M.S., Chang, A.E. and Li, Q. (2012) Targeting cancer stem cells via dendritic-cell vaccination. OncoImmunology, 8, 1401-1403. doi:10.4161/onci.21026

[14] Aarntzen, E.J.G., De Vries, I.J.M., Lesterhuis, W.J., Schuurhuis, D., Jacobs, J.F.M., Bol, K., Schreibelt, G., Mus, G., De Wilt, J.H.W., Haanen, J.B.G., Schadendorf, D., Croockewit, A., Willeke, A., Blokx, A.M., Van Rossum, M.M., Kwok, W.W., Adema, G.J., Punt, C.J. and Figdor, C.J. (2012) Targeting CD4 T-helper cells improves the induction of antitumor responses in dendritic cell-Based vaccination. Cancer Research, 73, 1-11.

[15] Lechner, M.G., Russell, S.M., Bass, R.S. and Epstein, A.L. (2011) Chemokines, costimulatory molecules and fusion proteins for the immunotherapy of solid tumors. Immunotherapy, 3, 1317-1340. doi:10.2217/imt.11.115

[16] Mellman, I., Coukos, G. and Dranoff, G. (2011) Cancer immunotherapy comes of age. Nature, 480, 22-29. doi:10.1038/nature10673

[17] Dauer, M., Schnurr, M. and Eigler Dauer, A. (2008) Dendritic cell-based cancer vaccination: Quo vadis? Expert Review of Vaccines, 7, 1041-1053. doi:10.1586/14760584.7.7.1041

[18] Kirkwood, J.M., Butterfield, L.H., Tarhini, A.A., Zarour, H., Kalinski, P. and Ferrone, S. (2012) Immunotherapy of Cancer in 2012. Cancer Journal for Clinicians, 62, 309335. doi:10.3322/caac.20132

[19] Pandolfi, F., Cianci, R., Pagliari, D., Casciano, F., Bagalla, C., Astone, A., Landolfi, R. and Barone, C. (2011) The immune response to tumors as a tool toward immunotherapy. Clinical and Developmental Immunology, 2011, Article ID: 894704. doi:10.1155/2011/894704 
[20] Bu, D., Tarrio, M., Maganto-Garcia, E., Stavrakis, G., Tajima, G., Lederer, J., Jarolim, P., Freeman, G.J., Sharpe, A.H. and Lichtman, A.H. (2011) Impairment of the programmed cell death-1 pathway increases atherosclerotic lesion development and inflammation. Arteriosclerosis, Thrombosis, and Vascular Biology, 31, 1100-1107. doi:10.1161/ATVBAHA.111.224709

[21] Pardoll, D.M. (2012) The blockade of immune checkpoints in cancer immunotherapy. Nature, 12, 252-264.

[22] Wells, A.D. (2009) New insights into the molecular basis of T cell anergy: Anergy factors, avoidance sensors, and epigenetic imprinting. The Journal of Immunology, 182, 7331-7341. doi:10.4049/jimmunol.0803917

[23] Liu, Q and Gao, B. (2008) Manipulation of MHC-I/TCR interaction for immune therapy. Cellular \& Molecular Immunology, 5, 171-182. doi:10.1038/cmi.2008.21

[24] Mescher, M.F., Popescu, F.E., Gerner, M., Hammerbeck, C.D. and Curtsinger, J.M. (2007) Activation-induced nonresponsiveness (anergy) limits CD8 T cell responses to tumors. Seminars in Cancer Biology, 17, 299-308. doi:10.1016/j.semcancer.2007.06.008

[25] Carreno, B.M. and Collins M. (2002) The B7 family of ligands and its receptors: New pathways for costimulation and inhibition of immune responses. Annual Review of Immunology, 20, 29-53. doi:10.1146/annurev.immunol.20.091101.091806

[26] Park, J.J., Omiya, R., Matsumura, Y., Sakoda, Y., Kuramasu, A., Augustine, M.M., Yao, S., Tsushima, F., Narazaki, H., Anand, A., Liu, Y., Strome, S.E., Chen, L. and Tamada, K. (2010) B7-H1/CD80 interaction is required for the induction and maintenance of peripheral T-cell tolerance. Blood, 116, 1291-1298. doi:10.1182/blood-2010-01-265975

[27] Taylor, P.A., Lees, C.J., Fournier, S., Allison, J.P., Sharpe, A.H. and Blazar, B. R. (2004) B7 expression on T cells down-regulates immune responses through CTLA-4 Ligation via R-T Interactions. The Journal of Immunology, 172, 34-39.

[28] Hatam, L.J., De Voti, J.A., Rosenthal, D.W., Lam, F., Abramson, A.L., Steinberg, B. and Bonagura, V.R. (2012) Immune suppression in premalignant respiratory papillomas: Enriched functional CD4Foxp3 regulatory T cells and PD-1/PD-L1/L2 expression. Clinical Cancer Research, 18, 1925-1935. doi:10.1158/1078-0432.CCR-11-2941

[29] Carreno, B.M., Bennett, F., Chau, T.A., Ling, V., Luxenberg, D., Jussif, J., Lorea Baroja, M. and Madrenas, J. (2000) CTLA-4 (CD152) can inhibit T cell activation by two different mechanisms depending on its level of cell surface expression. The Journal of Immunology, 165, 13521356.

[30] Griffin, M.D., Hong, D.K., Holman, P.O., Lee, K.M., Whitters, M.J., O’Herrin, S.M., Fallarino, F., Collins, M., Segal, D.M., Gajewski, T.F., Kranz, D.M. and Bluestone, J.A. (2000) Blockade of $\mathrm{T}$ cell activation using a surface-linked single-chain antibody to CTLA-4 (CD152). Journal of Immunology, 164, 4433-4442.

[31] Agata, Y., Kawasaki, A., Nishimura, H., Ishida, Y., Tsubata, T., Yagita, H. and Honjo, T. (1995) Expression of the
PD-1 antigen on the surface of stimulated mouse $\mathrm{T}$ and $\mathrm{B}$ lymphocytes. International Immunology, 8, 765-772.

[32] Feyler, S., Scott, G.B., Parrish, C., Jarmin, S., Evans, P., Short, M., McKinley, K., Selby P.J. and Cook, G. (2012) Tumour cell generation of inducible regulatory T-cells in multiple myeloma is contact-dependent and antigen-presenting cell-independent. PlosOne, 7, Article ID: e35981. doi:10.1371/journal.pone.0035981

[33] Topfer, C., Kempe, S., Muller, N., Schmitz, M., Bachmann, M., Cartellieri, M., Schackert, G. and Temme, A. (2011) Tumor evasion from T cell surveillance. Journal of Biomedicine and Biotechnology 2011, Article ID: 918471. doi:10.1155/2011/918471

[34] Hardy, B., Dotan, D. and Novogrodsky, A. (1989) A monoclonal antibody to human B lymphoblastoid cells activates human and murine T lymphocytes. Cell. Immunol, 118, 22-29. doi:10.1016/0008-8749(89)90354-7

[35] Hardy, B., Yampolski, I., Kovjazin, R., Galli, M. and Novogrodsky, A. (1994) A monoclonal antibody against a human B lymphblastoid cell line induced tumor regression in mice. Cancer Research, 54, 5793-5796.

[36] Hardy, B., Kovjazin, R., Raiter, A., Ganor, N. and Novogrodsky, A. (1997) A lymphocyte-Activating monoclonal antibody induces regression of human tumors in severe combined immunodeficient mice. Proceedings of the National Academy of Sciences of the United States of America, 94, 5756-5760. doi:10.1073/pnas.94.11.5756

[37] Hardy, B., Indjiia, L., Rodionov, G., Raiter, A. and Inbal A. (2001) Treatment with BAT monoclonal antibody decreases tumor burden in a murine model of leukemia/ lymphoma. International Journal of Oncology, 19, 897902.

[38] Hardy, B., Morgenstern, S., Raiter, A., Rodionov, G., Fadaeev, L. and Niv, Y. (2005) Immunotherapy of human colorectal hepatic metastases in mice by BAT monoclonal antibody. Cancer Letters, 229, 217-222. doi:10.1016/j.canlet.2005.06.046

[39] Feinmesser, M., Raiter, A. and Hardy B. (2006) Prevention of melanoma metastases in lungs of BAT treated and peptide immunized mice. International Journal of Oncology, 29, 911-917.

[40] Raiter, A., Rodionov, G., Novogrodsky, A. and Hardy, B. (2000) $\mathrm{CD}^{+} \mathrm{T}$ lymphocytes as a primary cellular target for BAT monoclonal antibody stimulation. International Immunology, 12, 1623-1628.

doi:10.1093/intimm/12.11.1623

[41] Berger, R., Rotem-Yehudar, R., Slama, G., Landes, S, Kneller, A., Leiba, M., Koren-Michowitz, M., Shimoni, A. and Nagler, A. (2008) Phase I safety and pharmacokinetic study of CT-011, a humanized antibody interacting with PD-1, in patients with advanced hematologic malign-nancies. Clinical Cancer Research, 14, 3044-3051. doi:10.1158/1078-0432.CCR-07-4079

[42] Topalian, S.L., Hodi, F.S., Brahmer, J.R., Gettinger, S.N., Smith, D.C., McDermott, D.F., Powderly, J.D., Carvajal, R.D., et al. (2012) Safety, activity, and immune correlates of anti-PD-1 antibody in cancer. The New England Journal of Medicine, 366, 2443-2454. doi:10.1056/NEJMoa1200690 